\title{
Battling chronic pain and learning self- advocacy: the long journey of becoming pain free
}

\author{
Mary Johnson
}

\section{EARLY SIGNS}

I had returned to running for about 6 months following a stress fracture in my left femur when I started noticing pain high up in my right hamstring. It got to the point where I knew something was wrong, but it didn't hurt to run. My massage therapist/strength coach and physical therapist said that if I could run without pain, it would be fine, so I continued to run. A lot. Six months after the pain began, I was doing a ton of volume leading up to the 2016 Boston Marathon. It still didn't hurt when I ran, but the pain after training continued to worsen. By this time, I was worried I had a pelvic stress fracture. I saw an orthopaedic doctor, who told me that I didn't have a stress fracture and was okay to just run through the discomfort. In addition to the work I'd done to return from my femoral stress fracture, my husband and I also wanted to start a family, so I viewed this as my last chance to run marathons pre-baby. When I ran a marathon in April 2016, then another in May 2016... it wasn't a good decision, but I thought it was at least an informed decision.

\section{LOOKING FOR ANSWERS}

By the fall of 2016, my hamstring tightness had gotten to the point that I couldn't touch my toes. I also started to have similar symptoms on the left side. As an athlete, I thought 'I've got the approval of my support team, I'm going to be okay.' I ran another marathon, before deciding to take time off, hoping the issues would resolve with rest. But rest didn't help; even after 4 weeks off, my hips and pelvis were so tight, I thought I might have a bigger issue. My orthopaedic doctor ordered a pelvic MRI, told me it showed hamstring oedema on both sides, and recommended rehabilitation. My physical therapist gave me a pretty aggressive hamstring-focused strength programme; after a couple of months, the symptoms on the left side resolved, while the symptoms on the right side persisted. At this point, I did my own research, then went back to my orthopaedic doctor and asked about
PRP (platelet-rich plasma). I encountered a lot of administrative and insurance roadblocks. My doctor advocated for me and eventually got it done.

A few months after the injection, I realised that I still had pain, but it wasn't coming from my hamstring-it was in my back. I messaged my orthopaedic doctor and she ordered a lumbar MRI and referred me to a spine surgeon. At my consultation, the spine surgeon had my lumbar MRI on the screen. I pointed to where I was having pain, and he said it was no wonder, as I had swelling around an unhealed sacral stress reaction. The way he said it-he even started laughingfelt belittling. He recommended rest, and prescribed a sacroiliac injection, which confirmed his hypothesis that the pain was stemming from my back. He told me the rest of my spinal MRI was "pristine," so he couldn't help me unless I wanted a spinal fusion. I started crying and was upset, because it had been months of no progress, and now, I had no plan. He gave me a box of tissues, a physiatrist referral, and had a nurse escort me out. And that was that.

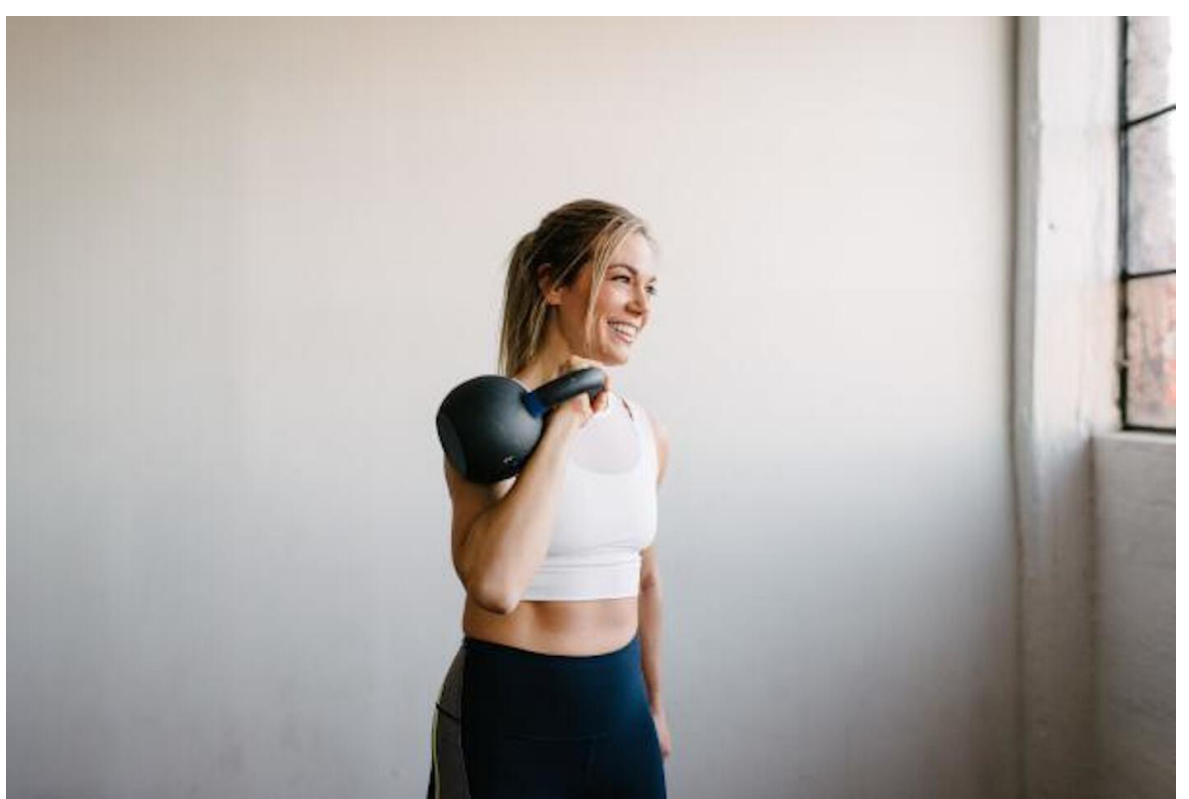

Figure 1

\section{TURNING POINT}

My experience with the physiatrist was completely different. Her clinical assessment wasn't anything crazy; she checked my back, hips and knees. She looked at the same MRIs. But I knew that I was going to be my best advocate, so I went in with questions written down. She listened to me, answered my questions, and talked me through her thought process. Her plan wasn't just based on my MRI results; it also took into account what I said. She helped me understand how different parts of my experience may be connected. When something didn't work-like the facet joint injections we tried; she didn't give up, she adapted. She eventually recommended a caudal injection. Two weeks after the caudal injection (spring 2018), all the pain through my hips and pelvis resolved. I was eventually able to build back up my running, to the point where I was able to start training for a marathon again. The symptoms returned during my pregnancy in 2019, and lasted for several months postpartum, but they resolved with rehab and strengthening. Today, I'm the healthiest and strongest I've ever felt in my life. That's not a position that I ever thought I would be in.

\section{REFLECTING ON THE JOURNEY}

Oftentimes I feel that because I'm an athlete and a coach, because I'm strong, I get overlooked. Each doctor that I saw had a different approach. The orthopaedic doctor was almost too casual of a relationship; like maybe she respected my understanding of my body as an athlete too much. She also 
only told me what supported her plan. I emailed her after I saw the spine surgeon and asked why she didn't mention anything about the sacral oedema. Her response-that she noticed it, but since my initial complaint was the hamstring, that's where she chose to focus-never addressed why she didn't tell me about all of my result findings and then her subsequent thought process. The spine surgeon was just an asshole; he didn't care about what I had to say and was only interested in one course of action. He didn't see me past my MRI at all. With the physiatrist, it was very much a doctor/patient relationship; she respected what I had to say, but she always maintained her authority. Yes, I was an athlete and a coach, but I was also a patient looking for help. Her communication style helped me respect her authority because I felt like she saw and respected me. The trust in the doctor-patient relationship was built from here. So, my takeaway from this 18-month-long odyssey is this: listen, educate and uphold authority, without being an asshole. Even your most difficult patients (I was certainly one of them) will thank you for it.

Funding The authors have not declared a specific grant for this research from any funding agency in the public, commercial or not-for-profit sectors.

Competing interests None declared.
Patient and public involvement Patients and/or the public were involved in the design, or conduct, or reporting, or dissemination plans of this research. Refer to the Methods section for further details.

Patient consent for publication Obtained.

Provenance and peer review Commissioned; internally peer reviewed.

(C) Author(s) (or their employer(s)) 2021. No commercial re-use. See rights and permissions. Published by BMJ.

\section{(A) Check for updates}

To cite Johnson M. Br J Sports Med 2021;55:123-124.

Accepted 3 June 2020

Published Online First 25 August 2020

Br J Sports Med 2021;55:123-124.

doi:10.1136/bjsports-2020-102297 